\title{
Women had an inherent sense of knowing how to manage their lives after sexual assault by men they knew
}

Draucker CB. Knowing what to do: coping with sexual violence by male intimates. Qual Health Res 1999 Sep;9:588-601.

QUESTION: What is the meaning of sexual violence in the lives of women who have been sexually assaulted by men they knew well?

\section{Design}

Heideggerian hermeneutics.

\section{Setting}

Northwestern Ohio, USA.

\section{Participants}

10 women $>18$ years of age (age range $19-57 \mathrm{y}, 8$ white, 2 African-American) who had been sexually assaulted as adults by men they knew well were recruited by public announcements. 7 of the women had experienced childhood abuse or neglect, and many had several abusive relationships as adults.

\section{Methods}

1-3 hour interviews were held with each woman and began with open ended questions about the meaning of the experience of sexual violence and how it affected their day to day lives. The author and another psychiatric nurse independently reviewed the interview transcripts, prepared written interpretations, and discussed and compared the interpretations. A qualitative research group also reviewed selected transcripts and commented on the emerging themes. 5 of the participants provided comments on a written draft of the author's interpretations.

\section{Main findings}

2 themes emerged. The first, dwelling with violence, reflected the women's stories of feeling unsettled and unprotected amidst the violence in their lives, and is discussed in another paper. ${ }^{1}$ The second, knowing what to $d o$, reflected women's descriptions of how they intuitively knew how to manage their lives during and after the violence, and is the focus of this article.

Women told stories of managing their lives in a violent world by "getting past it" and "carrying on". All participants said that they had to figure things out on their own, some because they did not receive help from the institutions charged with helping them (eg, hospital emergency departments and work environments where the incidents occurred); some said that they wanted to decide for themselves how to deal with the violence. The women gave examples of knowing how to survive a particular assault or a lifetime of violence, attempting to stay safe, and making things better. Surviving a particular assault involved knowing whether to resist or succumb; one woman said that women know what to do in the situation and that others should not second guess a woman's decision to fight or to comply during an assault. Surviving a lifetime of violence was, for some, supported by finding "better things to do", such as involvement with music, caring for children, or finding meaningful employment. In attempting to stay safe, women did things differently in their relationships or everyday routines to prevent further violence (eg, avoiding dangerous situations and dangerous men). Women did things to help themselves "feel better" (eg, reading self help books or writing in a journal); "get better" (eg, learning assertiveness); "make a better life" (eg, taking training to secure a job); and "make things better for others" (eg, participating in the study).

\section{Conclusion}

Women who experienced sexual violence by men they knew well had an inherent sense of knowing what to do and managed their lives by engaging in activities that they knew were sensible for them in their circumstances.

1 Draucker CB, Madsen C. Women dwelling with violence. Image J Nurs Sch 1999;31:327-32.

\section{COMMENTARY}

Women's roles in actively dealing with violence have been undervalued in both lay and professional discourses, where women are often portrayed as victims and their ability overlooked. This study by Draucker adds to the growing literature that attends to and values the perspectives of women who experience violence.

Draucker uses Heideggerian hermeneutics deftly and makes it easily understandable. The method is particularly effective as it offers analysis of both the constraints imposed by the violent worlds in which women live, and women's room to manoeuvre within those constraints.

The women in this study experienced multiple forms and episodes of violence, and several discussed general maltreatment of women. Thus, as Draucker notes, the stories reflect ways of dealing with various forms of abuse, and for some, with a "lifetime of violence". The findings are, therefore, less about dealing with a particular sexual assault and more about living in a violent world. The findings may be most reflective of women with multiple experiences of violence, or may be widely reflective of women living in violent societies. Although it is important to emphasise women's ability, such understanding must not overshadow needs for meaningful support, nor absolve professionals of providing support. Having "know-how" did not mean that the women did not need support. In fact, many "figured things out for themselves" after failure of systems to which they turned. Rather than using "all-victim" or "all-agent" approaches, ${ }^{1}$ we must counter stereotypes and respect women's acts of struggle, while continuing to support those acts.

The study emphasises respecting women's know-how and the importance of listening rather than questioning or advising. Awareness of women's inherent sense of how to manage may encourage nurses to work with women collaboratively, without dictating choices.

Colleen Varcoe, RN, PhD Assistant Professor, School of Nursing University of Victoria Vancouver, British Columbia, Canada

1 Mahoney MR. Victimization or oppression? Women's lives, violence, and agency. In: Fineman MA, Mykitiuk R, editors. The public nature of private violence: the discovery of domestic abuse. New York: Routledge, 1994:59-92. 